\title{
The English School and the Classical Approach: Between Modernism and Interpretivism
}

\author{
Mark Bevir and Ian Hall
}

Paper for special issue of the Journal of International Political Theory (forthcoming, 2020).

The English school of international relations has long been criticised for an apparent lack of clarity about its preferred approach to researching the field (see, for example, Copeland 2003 or Finnemore 2001). Indeed, some have gone so far as to suggest that the school is characterised by 'methodological naïveté' (Holsti 2009: 126). In response, some in the English school argue that an absence of commitments to particular philosophical and methodological positions is actually an advantage, because it supposedly provides its adherents more analytical flexibility than its competitors (see, for example, Little 2000). Others have responded by seeking to clarify a set of methods they think appropriate for the school (see especially Navari 2009; cf. Murray 2013). Rightly, in our view, they contend that the school stands for more than just a concept or set of concepts, as Little (2000) or Buzan (2014) suggest, and that it represents a distinctive way of studying international relations.

We argue, however, that not enough has yet been done to lay out the philosophical commitments of the school and its key figures, despite the pioneering work of Suganami (1983), Dunne (1998), and others. This work is necessary, we think, both because the early school did stand for a particular, so-called 'classical approach' distinct from other contemporary schools of thought, and because the interpretivism of some of its members holds out the possibility of developing new and valuable research agendas in contemporary International Relations (IR). This article 
therefore seeks to explain the foundations of the English school's so-called 'classical approach' (Bull 1966) and to make the case for re-grounding the contemporary school in a thoroughgoing interpretivism. It revisits the work of the early school, especially the work of Herbert Butterfield, Martin Wight, and Hedley Bull. To better grasp their commitments, it discusses their work in the wider context of intellectual debates about the study of history and politics that arose after the end of the First World War. In particular, it situates it in the crisis of what we call 'developmental historicism' and the emergence of the modernist social sciences. The article then traces how the classical approach emerged as a response to those two pressures and why it took the form that it did, as a kind of halfway house between interpretivism and modernism. ${ }^{1}$

Throughout, we highlight the early English school's commitments to interpretivist positions: to historicism and historical explanation; to the investigation of beliefs, theories, ideas, and ethical principles, and their relationship to social institutions, norms, and rules; and to explaining social behaviour by reference to the meanings that actions have for socially situated agents. ${ }^{2}$ We recognise, of course, that parts of the early English school - and indeed the revived school, from the mid 1990s onwards - are also committed to other approaches borrowed from what we call the 'modernist social sciences'. But we argue that this borrowing - which over time produced what we call a kind of 'reluctant modernism' ${ }^{3}$ - undermines the claim that the 'classical approach' offers a distinctive and superior way of researching international relations, fueling the charge that it is confused and naive. In sum, we suggest that a thoroughgoing interpretivism offers both a better way of doing social science and a better foundation for the English school.

\section{The origins of the classical approach}


Like the wider field of International Relations in Britain, the English school was established by scholars from different disciplines, including law, philosophy, and theology. Historians, however, predominated (Dunne 1999; Hall 2012; Hall 2019). Their disciplinary background and beliefs shaped the evolution of the field, the school, and the classical approach. But so too did developments within history and within the social sciences in the inter-war and post-war years to which they had to respond, especially the collapse of 'developmental historicism' and the rise of modernist social science. The reluctant modernist 'classical approach' took the form that it did, we argue, because it was a compromise: it attempted to preserve a historicist orientation - albeit shorn of the progressivism inherent in development historicism - while incorporating some modernist aims and methods.

\section{Developmental historicism and modernist empiricism}

Developmental historicism was the dominant approach to the study of history and politics in the late nineteenth and early twentieth centuries (Bevir 2016; Bevir 2017: 1-16; Burrow 1981; Collini, Winch and Burrow 1983; den Otter 1996). It was historicist in that it assumed that at different times societies had different beliefs, practices, and institutions. It was 'developmental' because it held that each successive society in history displayed superior beliefs, practices, and institutions, demonstrating progress over time. It was influenced by romanticism, which emphasised the ability of human agents to make and remake social life; whiggism, which viewed history as story of the eventual triumph of political forms that upheld personal liberty; and Hegelian Idealism, which conceived history progressing through stages in which greater human freedom was achieved at each stage, culminating in the creation of nation-states (Bevir 2006: 585-586). 
Developmental historicists produced narratives that demonstrated continuity and progress in social life. Both historians and political scientists used these narratives to try to educate present political practitioners and the public, affirming J. R. Seeley's aphorism that 'History without political science has no fruit; political science without history has no root' (den Otter 2007, 37; cf. Bryce 1909). They focused on the evolution of ideas and institutions - especially on those that developmental historicists believed had progressively banished falsehood and tyranny - and constructed narratives that aimed to demonstrate how such progress had come about. At the same time, they considered the research they undertook to be scientific, in so far as they were committed to inductive empiricism, and believed it properly consisted of the systematic analysis of historical artefacts.

The First World War plunged developmental historicism into crisis, undermining confidence in progress, in Western social institutions as the pinnacle of human achievement, and in the nation-state as the best vehicle for the realization of human liberty (Bevir 2017: 5; cf. Blaas 1978). It also fueled doubts about the value of history and the historical profession, both of which had been put in the service of the nation-state during the conflict, with historians enlisted in wartime as political advisors and propagandists. Critiques of developmental historicism emerged (including Namier 1929; Butterfield 1931), opening the door to modernist approaches to studying the past and the social sciences (Bentley 2006; Ross 1991).

Modernists followed Emile Durkheim's call to treat 'social facts as things' akin to natural phenomena (Hollis 1994: 99). They set aside historical narratives as the best means of explaining social life in favour of new typologies, schemes, and measurements, dividing the world into discrete and discontinuous units that could be compared and manipulated (Bevir 2017). Modernists focused on processes, functions, 
and systems, exploring the relationships between different elements of what developmental historicists had treated as a social whole. To explain human behaviour, they turned away from the established canons of ethics and political theory, moving instead towards economics and psychology (see, for example, Wallas 1908).

The rise of modernism did not mean an end to historical research. But it did mean that narratives occupied a smaller place in political science and public policy, and even in academic history. Many historians also adopted modernist topics and techniques, borrowing from economics, psychology, sociology, and statistics (Saler 2017). Social scientists increasingly shunned original historical research, relying instead on syntheses of existing scholarship to provide the material they needed for their studies of contemporary politics. They used history more as a source of data and they used historical narratives less often as the means for explaining those data. Their theories and explanations relied more on atomization, classification, statistical correlations, or identification of functions within a system (see Bevir 2017).

The crisis of developmental historian and the rise of modernism did not entail a complete end to historicism either. Before the First World War, some radical historicists like Benedetto Croce (1921) had begun to reject developmentalism and progressivism, while continuing to assert the ubiquity of change in social life and the necessity to interpret political events and behaviour in their historical contexts. In the 1930s and 1940s in Britain, the Oxford philosopher R. G. Collingwood (see Collingwood 1946) and his Cambridge counterpart Michael Oakeshott (see Oakeshott 1933) championed similar views. They argued that historians should be sceptical of atomizing typologies, models, and correlations of modernist social science, and aim instead accurately to represent change and contingency in historical narratives 
reconstructed by way of inductive studies of human life in past contexts. In this way, historicism survived, but shorn of the link with developmentalism. ${ }^{4}$

\section{The origins of the classical approach}

The English school's founders - especially Herbert Butterfield and Martin Wight - were deeply affected, both positively and negatively, by the crisis of developmental historicism. In the inter-war years, Butterfield played a major role in critiquing it (Bentley 2011, 95-118; cf. Butterfield 1931). Both scholars disliked its innate progressivism and complained that its narratives were often moralistic. They deprecated its indulgent treatment of nationalism and its assumption that the nationstate was the best means to deliver liberty (Hall 2002, 735-736; Hall 2006, 65-85). They did not, however, think that modernist social science was preferable. In general, they worried that it too was implicitly progressivist, and argued that it was too narrowly utilitarian. In response, they developed approaches to the study of international relations that kept history at its core, retained a focus on ideas and institutions, made use of elements of modernist empiricism in an attempt to hold progressivism and moralism at bay, and adopted elements of radical historicism. In this way, the early English school laid the groundwork for what we call the 'reluctant modernism' that, we argue, emerged especially with Bull.

\section{A science of statecraft?}

Butterfield argued that developmental historicism produced bad history and threatened to turn historians into propagandists (Butterfield 1931). He urged historians to produce what he called 'technical history' instead, relying on inductive empiricism and purging themselves of present-minded prejudice by what he called 
'self-emptying'. He argued that they should aim to construct neutral narratives of historical events that could be accepted by all or most observers (Butterfield 1944; Butterfield 1951a, 133). He knew that this was an unattainable ideal, recognising that present-mindedness always crept in and that 'imaginative sympathy' was needed to write good history (Butterfield 1955, 170; cf. Bentley 2011, 233-259). But he still thought that professional historians ought to strive to realise it - and be seen to strive for it - if they were to avoid becoming and being perceived as political partisans (Bentley 2011, 95-118).

Butterfield favoured a modernist historiography in which the rigorous application of historical method might generate authoritative narratives, as opposed to what he saw as prejudiced, often moralistic stories of developmental historicists. $\mathrm{He}$ was not, however, enthusiastic about the modernist social sciences and their aspirations to inform policy. With IR specifically in mind, he argued they often produced 'dabblers in a journalistic type of thinking' who were too 'direct' in their 'utilitarian intention' (Butterfield 1949, 2-3). He believed that history provided a better training for both scholars and practitioners. In his view, history was more 'scientific' than the social sciences, since it supposedly inculcated a dispassionate, open-minded, and methodical approach to evidence and argument, and could nurture a more nuanced understanding of the human condition (Butterfield 1951b).

At the same time, he did pursue a 'science of statecraft' underpinned by his preferred approach to the past. From the late 1930s to the early 1970s, he explored a series of other attempts to generate such a 'science', especially Machiavelli's (Butterfield 1940) and Napoleon's (Butterfield 1939), and read widely in American IR, especially in classical realism (see Hall 2002, 727-734; cf. Butterfield 1953; 1960; Coll 1985). Butterfield believed that what he called the 'geometry' of international 
relations might be possible, but rejected the search for covering laws (Butterfield 1960, 51; cf. Butterfield 1975). Even if such things could be found, he believed, human agents, endowed with free will, could (and would) defy social scientists' expectations and break the 'rules'.

Butterfield's 'geometry' consisted instead of those explicit and tacit rules of conduct that he thought 'statesmen' used to construct and maintain international order. Order came into being, he argued, when 'statesmen' held the right beliefs about how international relations ought to be managed, and behaved accordingly. His 'science' was a search for those right beliefs, which he judged reached their highest point of sophistication in eighteenth-century European diplomacy. The theory and practice of that era, he argued, dedicated itself to the essential tasks of upholding the 'balance of power' and keeping ideology and moralism out of 'international society' (see Butterfield 1966). For Butterfield, then, the object of IR was to investigate such beliefs, explain the reasons why successful 'statesmen' adhered to them, and why they acted as they did. If that is what it did, IR might help to inform policymakers, who could draw on the stock of wisdom thus generated. Despite Butterfield's modernist emphasis on method, in other words, his science of statecraft was interpretivist, focused on explaining the actions of historically situated agents in terms of the meanings those actions have for those performing them.

\section{International Relations as historical interpretation}

Wight was more hostile to modernism than Butterfield, despite his doubts about developmental historicism. He disliked the confident nationalism of developmental historicists and found their progressivism incompatible with his Christian faith, since it ran counter to his conviction that secular history has no 
direction or meaning (Hall 2006, 38-40; 53-54). But he was also sceptical about modernist history, arguing it was epistemologically naïve. Wight rejected the idea that ‘technical history' was possible and satirised modernist historians as bloodless 'prophets of historiographical cybernetics' (quoted in Hall 2006, 46). He preferred the historicist interpretivism of Croce and Collingwood. He recognized that historical facts do not exist independently of historians - they are made, not found; and depend on prior knowledge acquired by socialisation about what constitutes them. For that reason, he rejected "the old-fashioned positivist belief in "the facts"... as something separable from their interpretation' (quoted in Hall 2006, 51).

Wight spent much effort in the late 1940s and 1950s wrestling with the challenge of how best to approach IR. His early foray, in the Chatham House pamphlet Power Politics, produced a kind of taxonomy of international rules and conventions, laying out different understandings of concepts like 'great power' or 'alliances' (Wight 1946). When he arrived at the London School of Economics in 1949 , Wight was confronted by the new approaches to the field being employed there and nearby. He was not wholly convinced, however, by the argument of C. A. W. Manning, that IR should be understood as 'meta-diplomatics' - a kind of Wittgensteinian game whose rules scholars should focus on discerning (Manning 1962, x; 200-216; cf. Jackson 2020). ${ }^{5}$ At the same time, he was repelled by the principal alternative to Manning's interpretivism - the modernist, mechanistic, sociological approach, focused on the role and distribution of power, favoured by Georg Schwarzenberger at University College, London (Hall 2006, 90-91; cf. Schwarzenberger 1951).

Instead, Wight settled uncomfortably into the position that IR should involve a blend of 'contemporary history' and something that he called the 'Sociology of the 
International Community' - essentially the study of the norms, rules, and institutions particular to the practice of inter-state relations (Wight 1950). The latter involved compromising with the modernist social sciences, adopting the comparative method and borrowing some concepts, like that of an 'institution', from anthropology and sociology. ${ }^{6} \mathrm{He}$ did not believe, however, that IR ought also to accept what he called the 'pragmatic' orientation of the social sciences, and welcomed the fact that his LSE students 'did not regard International Relations as being of any use' (Wight 1950). Wight's teaching in the 1950s, on both international institutions and later on theory, reflected both convictions: his lectures involved trans-historical comparisons of ideas and institutions, but without prescription or what we would call now 'policy relevance' (Hall 2006, 113-114; Wight 1990). ${ }^{7}$

After a decade of contemplating the problem, Wight decided that 'Politics: International Politics $=$ Political Theory: Historical Interpretation' (Wight 1966a, 33) He concluded that ' $[\mathrm{w}]$ orks of international history... convey the nature of foreign policy and the working of the state-system better than much recent theoretical writing based on the new methodologies'. 'It is not simply', Wight argued:

...that historical literature is doing a different job from systems analysis. Historical literature at the same time does the same job - the job of offering a coherent structure of hypotheses that will provide a common explanation of phenomena; but it does the job with more judiciousness and modesty, and with closer attention to the record of international experience (Wight 1966a, 32)

Wight was not talking here about mere technical histories or neutral narratives, as Butterfield envisaged them. The kind of history he had in mind was work that had 
some kind of underlying 'philosophy of history' that gave the story 'theoretical coherence' (Wight 1955: 284). It explains as well as describes, by reference to that underlying philosophy. But the best history, he thought, was history with a moral, especially history-as-tragic-drama, in which the narrative of events and theory that informed it was underpinned by a deeper conception of the human predicament (see Chiaruzzi 2016; cf. Hall 2006, 59-60).

Wight's own approach to IR was straightforward. Like Butterfield, he focused on ideas, ranging across Western thought from the Greeks onwards in search of snippets of 'international theory' in the reflections of practitioners or the thought of scholars (see especially Wight 1966a; 1966b; 1990; 2005). This project was underpinned by the conviction that these beliefs and arguments informed the behaviour of practitioners, positively and negatively, and that interpreting them helped explain their actions and their own interpretations, sincere or otherwise, of those actions. For heuristic purposes - especially for students - he used the comparative method to analyse the various elements of these beliefs and arguments, but this by no means committed Wight to modernism (Wight 1990). Instead, like Butterfield, he remained concerned with interpreting the meanings actions had for the - mainly diplomatic - actors who perform them.

\section{Investigations and Interpretations}

This concern was clear in Diplomatic Investigations (1966), a collection of essays originally presented at meetings of the British Committee on the Theory of International Politics (BCTIP) that Butterfield chaired, and Wight later led. In its preface, they presented an oblique but clearly interpretivist manifesto about their preferred approach to IR and to IR theory (Dunne and Hall 2019). ${ }^{8}$ They began with 
the observation that the phrase 'theory of international politics' was 'without wide currency or clear meaning' in Britain. Given this ambiguity, they took it 'to cover enquiry into the nature of the international states-system, the assumptions and idea of diplomacy, the principles of foreign policy, the ethics of international relations and war' - areas that they thought call 'for new approaches and for academic treatment' (Butterfield and Wight 1966: 11). On this basis, they drew contrasts between this understanding of the field and that evinced by their American counterparts: 'The British have probably been concerned more with the historical than the contemporary, with the normative than the scientific, with the philosophical than the methodological, with principles than policy’ (Butterfield and Wight 1966: 12). And they observed differences with between their approach and what they perceived as its 'antithesis' systems theory (Butterfield and Wight 1966: 12). ${ }^{9}$

Butterfield and Wight went on to identify three 'characteristics' of approach taken in the essays. The first they called their 'frame of reference', which was the 'the diplomatic community itself, international society, the states-system', not 'the limits and uses of international theory, nor the formulation of foreign policy-making'. The essays were concerned with the 'distinguishing marks' of that community: 'the way it functions, the obligations of its members, its tested and established principles of political intercourse'. The second was the absence of interest in 'an all-embracing theoretical framework' or 'general theory' - something which set the essays apart from systems theory, in particular. Instead, they took an 'empirical and inductive' approach, Butterfield and Wight observed, and adopted a historical 'point of view', including a commitment to exploring 'classical' thought they thought still relevant and useful (Butterfield and Wight 1966: 12). And the last was their 'pervading moral concern', apparent in the appreciation that politics is the realm of the 'contingent and 
unforeseen', in which 'agonizing decisions have to be made'. A key preoccupation was therefore clarifying the 'principles of prudence and moral obligation' that practitioners themselves perceive, act upon, negotiate, and of course transgress (Butterfield and Wight 1966: 13).

\section{Modernism and the classical approach}

Tantalising though its preface was, Diplomatic Investigations did not offer a full account of the preferred approach of the early English school, nor did it resolve the differences between those of its various members (Dunne and Hall 2019). Instead, that task was performed by a junior member of the BCTIP, Hedley Bull. The same year (1966) the book was published, his account of the 'classical approach' appeared in World Politics. Unlike Butterfield or Wight, however, Bull had not been trained as a historian, and partly as a result, his account reflected a different set of assumptions and concerns. His early interests lay more with philosophy, thanks in part to the charismatic Scottish philosopher, John Anderson, who had taught him at the University of Sydney. Anderson imparted to Bull commitments to philosophical realism and inductive empiricism that were at odds with Butterfield and Wight's idealism and interpretivism, but which opened the door to some forms of modernist social science (Jeffery 2008).

Bull argued that the classical approach 'derives from philosophy, history, and law, and that is characterized above all by explicit reliance upon the exercise of judgment and by the assumptions that if we confine ourselves to strict standards of verification and proof there is very little of significance that can be said about international relations'. Instead, what 'general propositions' that can be made 'must...derive from a scientifically imperfect process of perception or intuition' and 
thus 'cannot be accorded anything more than the tentative and inconclusive status appropriate to their doubtful origin' (Bull 1966: 361). ${ }^{10}$ Intuition and judgement were necessary instruments, Bull maintained, because some of the 'core questions' of international theory were 'at least in part moral questions, which cannot by their nature be given any sort of objective answer, and which can only be probed, clarified, reformulated, and tentatively answered from some arbitrary standpoint, according to the method of philosophy' (Bull 1966: 366).

Bull argued that even 'empirical questions' were impossible to answer 'scientifically' by formulating testable hypotheses, because too much of importance would be left out of the investigation. These included questions like 'If we can speak of a society of sovereign states, does it presuppose a common culture or civilization?' and 'What is the place of war in international society?' - questions Bull asserted were 'typical' of international theory, but not testable in the manner of behavouralism (Bull 1966: 367). To these questions 'logical and rigorous' answers could of course be found - and had been, by thinkers like 'Raymond Aron, Stanley Hoffmann, and Kenneth Waltz' - but not in ways behavouralists preferred. Their work, Bull maintained, was scientific 'in the sense of being a coherent, precise, and orderly body of knowledge', 'consistent with the philosophical foundations of modern science', but it was also modest, recognising the limits of what he took to be the dominant scientific approach (Bull 1966: 375).

Unfortunately, Bull spent more time dissecting the 'scientific approach' that he did not like than he did defending his 'classical' alternative. But what he did say, and what he wrote in a significant essay for Australian Outlook in 1972, made clear it was a form of 'reluctant modernism'. Although Bull's classical approach was derived from 'philosophy, history, and law' it was not reducible to them, still less just to 
history, which Butterfield and Wight suggested it might. Bull spelt this out in the later essay, writing 'I do not accept Martin Wight's equation - Politics: International Politics $=$ Political Theory: Historical Interpretation' (Bull 1972: 256). Confusingly, however, he still described his preferred approach as being 'historical' and still argued that IR should be 'studied historically' (Alderson and Hurrell 2000: 37).

For Bull, IR involved the study of the 'states-system' or 'international society', its 'classic norms' and practices. It did not, however, have its own 'recognisable methods and techniques', unlike fields like 'mathematics or history or philosophy or economics'. Instead, it is a field of 'contending approaches', including a 'historical' one that was characteristic of British IR (Bull 1972: 255). 'Historical study', Bull argued, 'was essential for four reasons' - so that scholars 'grasp' the 'singular nature' of the actors involved and that international politics is a 'temporal sequence of events'; 'because the historical literature of International Relations constitutes an education in itself'; because history 'provides the cases against which empirical generalisations have to be tested'; and because 'theory itself has a history' of which theorists should be aware (Bull 1972: 256). But at the same time, Bull rejected the idea that IR 'can or need be studied only historically', arguing that 'theoretical inquiry' in the field was a different kind of activity, including the identification, formulation, and investigation of generalisations (Bull 1972: 257).

In this way, Bull maintained a kind of historicism, but shifted the focus of the English school away from Butterfield and Wight's concerns with interpreting the beliefs and behaviour of 'statesmen' and the diplomatic community. His interest lay in the theorising of 'international society', rather than in exploring the international thought of particular past and present practitioners, and in the modernist project of generating generalisations about international society. He departed from Butterfield 
and Wight most clearly in positing that order in international relations could arise and could be maintained without the conscious management of 'statesmen' with a shared 'diplomatic culture'. In The Anarchical Society, he argued that 'all actual societies' displayed order grounded in rules that appeared to be 'universal': rules concerning the use of violence, the enforcement of agreements, and the possession of property (Bull 1995 [1977]: 5). International society - the society of states - was no different; where there is an international system of independent political communities in which there is a sufficient level of interaction, there are social rules (Bull 1995 [1977]: 8-9). Order in societies arises given these conditions, on this account, out of the reasoned responses of its members. It requires far less conscious management by practitioners than Butterfield or Wight believed, fearing as they did that without it, disorder ensued, since the members of a societies generally share 'elementary or primary goals' and a perception of 'common interests' (Bull 1995 [1977]: 51).

\section{Post-positivism and the new English school}

In 1972, Bull observed that the brief but ferocious so-called 'Second Debate' over method in which he had played a prominent role in the 1960s had now 'died down, and inquirers have returned to their proper preoccupations, which are with matters of substance rather than methodology' (Bull 1972: 259). He had a point: although a number of significant works by English school adherents appeared during the 1970s and 1980s, including books by Bull himself (1977b), Alan James (1986), Robert Purnell (1973), and John Vincent (1974), few discussed their approach or methods in any detail, lacking - it seems - the pressure to do so. Even when provoked by Roy E. Jones famous call for the 'closure' of the school (Jones 1981) on the grounds that its members 'ignore scientific procedure' and that their works were 
unsystematic and by Michael Nicholson's dissection of Wight's thought (Nicholson 1981), no systematic defence of the school's approach or methods was offered. ${ }^{11}$

Of course, the issue was not entirely neglected. In 1983, Hidemi Suganami provided an important account of what he took to be the English school's key commitments. He observed what he called its 'anthropological approach' and its rejection of behaviouralism; its 'reliance on [the] sociological methods' of 'ideal-type analysis, comparative case study, and Verstehen'; and its focus on the 'cluster of social rules, conventions, usages, and practices' held by practitioners of international relations that shape their behaviour (Suganami 1983: 2363-2365). He also drew attention to Manning's Wittgensteinian account of international society, with its argument that 'shared diplomatic assumptions' shape different orders (Suganami 1983: 2371-2374; cf. Suganami 2003; XXXX). In a similar vein, Peter Wilson argued that the defining features of the English school - in which he also included Manning were its focus on the ideas, concepts, theories, and beliefs regarding international relations held in 'minds of statesmen' and on the traditions of thought that underpin different understandings of international relations. It emphasised that international society was, Wilson observed, a 'notional society' of 'notional beings', such as sovereign states, and it sought what he called 'interpretive understanding' of these notions (Wilson 1989: 53).

It was not until the revival of the English school in the 1990s, however, that significant interrogation of these commitments took place. This debate was stimulated in part by the agenda advanced by Barry Buzan, one of the advocates of the school's resuscitation, which some adherents found irksome, and in part by the contemporary 'Fourth Debate' in IR between positivism and post-positivism, which focused more attention on philosophical and methodological arguments (see Smith, Booth and 
Zalewski 1996). For his part, Buzan envisaged a school that moved away from concentrating on what went on in the 'minds of statesmen' and on 'traditions of thought' towards a different kind of theorising more in keeping with the precepts and aspirations of modernism (Buzan 1993; Buzan 2001). This view was contested by some post-positivists, for whom the English school's scepticism about modernist approaches - especially to behaviouralism - was a virtue, not a weakness. For them, the school held open a space for interpretive approaches and normative theorising (see Hall 2001).

In parallel, a flurry of works appeared that co-opted elements of early English school thought to contemporary post-positivist theoretical agendas, returning to some of its core concerns or taking inspiration from Bull's mid-1960s stand against behaviouralism. ${ }^{12}$ There was a revival of interest in the history of international thought, stimulated in part by the publication of Wight's International Theory lectures from the late 1950s (Wight 1990). But rather than merely seeking to unearth old ideas compare them, and present them for 'statesmen' to consider, as Butterfield and Wight had done, the new historians aimed at dispelling disciplinary myths, recovering lost alternatives to present theories (including the English school - see Dunne 1998), and questioning modernist understandings of knowledge-production (see, for example, especially Der Derian 1995; cf. Bell 2001). There was also interest in the English school because of its overt normativity. Bull and R J Vincent's work on intervention (see Bull 1984; Vincent 1974) stimulated scholars working in international ethics, especially concerning human rights and humanitarianism (e.g. Dunne and Wheeler 1996). Even post-Marxist critical theories, especially Andrew Linklater, found the school and its approach useful, if only as a foil (see Linklater 1998). 
Several different accounts of how the English school ought to approach international relations evolved as a result, some moving Bull's reluctant modernist 'classical approach' towards a more interpretivist orientation and others towards a more enthusiastic embrace of modernist social science. The first argues that the school should focus its attention on normative theory and theorising, developing better accounts of the history of international thought and engaging with international political theory, as it has evolved since the late 1970s, to inform approaches to contemporary ethical challenges (see, for example, Dunne and Wheeler 1996; Rengger 1992). The second maintains that it ought to draw especially on social constructivism to develop its account of international society (see, for example, Dunne 1995; Reus-Smit 2002), taking it beyond what they took to be the problematic quasi-functionalist conceptualisation that appeared particularly in Bull's work. ${ }^{13}$ The third insists that it ought to embrace methodological pluralism, using both positivist and post-positivist approaches to analyse the international system and international society (Buzan 1993; Little 1995; Little 2000). The fourth returns to international history, but uses concepts and approaches drawn principally from modernist historical sociology to explore the evolution and globalization of international society (Buzan and Lawson 2015; Buzan and Little 2000; Dunne and Reus-Smit 2017). The revival of the school was accompanied, in other words, by the emergence of as yet unresolved differences about its approach. To critics, in turn, this reinforced the impression that it lacked a coherence position.

\section{Conclusion}

One promising way of extricating the English school from this situation would be to conceive it less as a site for discussion about 'international society', and to make 
it more of a standard-bearer for an interpretive approach to international relations. Such a move would be in keeping with the preferences of the early school, as we have argued. But more importantly it would also align it with a large and well-developed school of philosophy that has developed since the 1960s that is sceptical about naturalism and its application to the social sciences, that has informed a large and growing body of research in political science and public policy (Bevir and Blakely 2018: 18-64). This is not, of course, a wholly new argument - it has been made several times since the revival of the school in the 1990s, notably by William Bain (2007), Tim Dunne (2005), Roger Epp (1998), Robert H. Jackson (1995; 1996; 2000; 2009) and Richard Shapcott (1994), among others. Moreover, it is an approach implicit in the work of many prominent English school members, including Ian Clark, who has focused on what he calls 'the historical examination of the operating principles' of international relations or the 'ideology of international order' (Clark 1989: 1; cf. Clark 2005; Clark 2011), R. J. Vincent (Vincent 1974; 1986), and James Mayall (1990).

Of course, taking the English school in this direction means committing it to certain premises and removing some of the present ambiguity and confusion about foundational assumptions. In particular, it involves a conscious and whole-hearted embrace of anti-naturalism and historicism as philosophical premises - of the arguments that the social sciences cannot be modelled on the natural sciences and that any 'laws' of social behaviour that can be established can also be set aside by informed, historically-located agents capable of foiling modernist social scientists' expectations (Bevir and Blakely 2018: 3). It entails affirming the interpretivist 'proposition' that 'the social world must be understood from within' in the terms in which it is comprehended by those that inhabit it, 'rather than explained from 
without' (Hollis 2002: 16). It means defending the allied notions that agents make international relations, that their actions are not limited by structures and are shaped by their own understandings of the meaning they have for them and others, and that explaining those actions requires an account of their meanings to those who perform them.

In concrete terms, this would mean returning the English school to the study of agents and to seeing 'international society' as a contingent construct that exists in the minds of actors and observers, rather than some kind of structure, and using official documents and statements, but also memoirs, biographies, interviews, and other means of accessing the interpretations that actors have of their actions. It would not imply a complete turning away from interest in institutions, but it would involve affirming the early English school's position that they are also contingent mental constructs, socially-generated and sustained, reflecting the beliefs of engaged agents about their rules, usefulness and propriety. Not does it imply a wholesale rejection of methods that have developed within naturalist social science, including quantitative work, which can generate insights into the meanings of social behaviour (Bevir and Blakely 2018: 96-103). Of course, interpretivists tend to prefer methods that allow researchers some insight into the beliefs of actors, but these can include, for example, formal models, understood as heuristic tools.

Taking the school in an interpretivist direction would also open up new topics for study and the possibility of greater dialogue with others for a school often seen as internally focused and self-referential. These include interpretivists working fruitfully elsewhere in the social sciences, notably in political science and public policy, where extensive work has been done to explore how situated agents act and why they behave as they do (see Hay 2011). They also include scholars using similar approaches in IR, 
including social constructivists across the field (see, for example, Guzzini 2000), practice theorists in diplomatic studies (see Pouliot 2016), feminists working on the perceptions and self-perceptions of women practitioners (Stephenson 2019), and interpretivists in foreign policy analysis (see Oppermann and Spencer 2016). In short, a deeper engagement with the English school's interpretivist past would allow it not only to respond to its critics with a clear account of its underlying commitments, but open significance new avenues for research.

\section{Bibliography}

Alderson K and Hurrell A (2000) International society and the academic study of international relations. In: Alderson K and Hurrell A (eds) Hedley Bull on International Society. Basingstoke: Macmillan, pp.20-53.

Bain W (2007). Are there any lessons of history? The English school and the activity of being an historian. International Politics 44(5): 513-530.

Bell, D (2001) International relations: the dawn of a historiographical turn?, The British Journal of Politics and International Relations 3(1): 115-126.

Bellamy, A J and McDonald M (2004) Securing international society: towards an English school discourse of security. Australian Journal of Political Science 39(2): 307-330.

Bentley M (2006) Modernizing England's Past: English Historiography in the Age of Modernism, 1870-1970. Cambridge: Cambridge University Press.

Bentley M (2011) The Life and Thought of Herbert Butterfield: History, Science and God. Cambridge: Cambridge University Press. 
Bevir M (ed) (2016) Historicism and the Human Sciences in Victorian Britain.

Cambridge: Cambridge University Press.

Bevir M (ed) (2017) Modernism and the Social Sciences. Cambridge: Cambridge University Press.

Bevir M and Blakely J (2018) Why political science is an ethical issue, Political Studies 66(2): 425-441.

Bevir M and Blakely J (2019) Interpretive Social Science: An Anti-Naturalist Approach, Oxford: Oxford University Press.

Blaas P B M (1978) Continuity and Anachronism: Parliamentary and Constitutional Development in Whig Historiography and in the Anti-Whig Reaction between 1880 and 1939. The Hague: Martinus Nijhoff.

Bryce J (1909) Presidential Address to the Fifth Annual Meeting of the American Political Science Association. American Political Science Review 3(1): 1-19. Bull H (1966) International theory: the case for a classical approach. World Politics 18(3): 361-377.

Bull H (1972) International relations as an academic pursuit, Australian Outlook 26(3): 251-265.

Bull H (1977) Introduction: Martin Wight and the study of international relations. In: M. Wight, Systems of States, ed. Hedley Bull. Leicester: Leicester University Press, pp.1-20.

Bull, H (ed) (1984) Intervention in World Politics, Oxford: Clarendon.

Bull H (1995 [1977]) The Anarchical Society: A Study of Order in World Politics, $2^{\text {nd }}$. ed. London: Macmillan.

Burrow J (1981) A Liberal Descent: Victorian Historians and the English Past. Cambridge: Cambridge University Press. 
Burton J (1965) International Relations: A General Theory. Cambridge: Cambridge University Press.

Butterfield H (1931) The Whig Interpretation of History. London: G. Bell and Sons. Butterfield H (1939) Napoleon. London: Duckworth.

Butterfield H (1940) The Statecraft of Machiavelli. London: G. Bell and Sons. Butterfield H (1944) The Study of Modern History. London: G. Bell and Sons. Butterfield H (1949) Notes on: How far can and should the subject of International Relations be included in the curriculum for undergraduate students of History?, Butterfield Papers 130/2, Cambridge University Library. Butterfield H (1951a) History and Human Relations. London: Collins.

Butterfield H (1951b) The scientific versus the moralistic approach in international affairs. International Affairs 27(3): 411-422.

Butterfield H (1953) Christianity, Diplomacy and War. London: Epworth. Butterfield H (1955) Man on His Past: The Study of the History of Historical Scholarship. Cambridge: Cambridge University Press.

Butterfield, H (1960) International Conflict in the Twentieth Century: A Christian View, London: Routledge \& Kegan Paul.

Butterfield H (1966) The balance of power. In: Butterfield H and Wight M (eds) Diplomatic Investigations: Essays on the Theory of International Politics. London: George Allen \& Unwin, pp.132-148.

Butterfield H (1975) Raison d'état: The Relations between Morality and Government. University of Sussex: Martin Wight Memorial Lecture.

Butterfield H and Wight M (eds) (1966) Diplomatic Investigations: Essays on the Theory of International Politics. London: George Allen \& Unwin. 
Buzan B (1993) From international system to international society: structural realism and regime theory meet the English school. International Organization 47(3): $327-352$.

Buzan B (2001) The English School: an underexploited resource in IR. Review of International Studies 27(3): 471-488.

Buzan B (2014) An Introduction to the English School of International Relations. Cambridge: Polity.

Buzan B and Lawson G (2015) The Global Transformation: History, Modernity and the Making of International Relations. Cambridge: Cambridge University Press.

Buzan B and Little R (2000) International Systems in World History: Remaking the Study of International Relations. Oxford: Oxford University Press.

Clark I (1989) The Hierarchy of States: Reform and Resistance in the International Order. Cambridge: Cambridge University Press.

Clark I (2005) Legitimacy in International Society. Oxford: Oxford University Press. Clark I (2011) Hegemony in International Society. Oxford: Oxford University Press. Coll AR (1985) The Wisdom of Statecraft: Sir Herbert Butterfield and the Philosophy of International Relations. Durham: Duke University Press.

Collingwood RG (1946) The Idea of History, ed. Knox T. Oxford: Clarendon.

Collini S, Winch D, and Burrow J (1983) That Noble Science of Politics: A Study in Nineteenth-Century Intellectual History. Cambridge: Cambridge University Press.

Copeland D (2003) A realist critique of the English School. Review of International Studies 29(3): 427-441. 
Croce B (1921) Theory and History of Historiography, trans. Ainslie D. London:

George Harrap and Sons.

Der Derian J (ed.) (1995) International Theory: Critical Investigations. Basingstoke: Macmillan.

Dunne T (1995) The social construction of international society. European Journal of International Relations 1(3): 367-389.

Dunne T (1998) Inventing International Society: A History of the English School. Basingstoke: Macmillan.

Dunne T (1999) A British school of international relations, in J Hayward, B Barry, and A Brown (eds) The British Study of Politics in the Twentieth Century. Oxford: Oxford University Press, pp.395-424.

Dunne, T (2005) System, State and Society: How Does It All Hang Together?, Millennium: Journal of International Studies 34(1): 157-170.

Dunne T and Hall I (2019) Introduction. In Butterfield H and Wight M (eds) Diplomatic Investigations: Essays on the Theory of International Politics, new edition. Oxford: Oxford University Press.

Dunne T and Reus-Smit C (eds) (2017) The Globalization of International Society. Oxford: Oxford University Press.

Dunne T and Wheeler NJ (1996) Hedley Bull's pluralism of the intellect and solidarism of the will. International Affairs 72(1): 91-107.

Epp R (1998) The English School on the frontiers of international society: A hermeneutic recollection. Review of International Studies 24(5): 47-64.

Fawn R and Larkins J (eds) (1996) International Society after the Cold War: Anarchy and order Reconsidered. Basingstoke: Macmillan. 
Finnemore M (2001) Exporting the English school? Review of International Studies 27(3): 509-513.

Grader S (1988) The English school of international relations: evidence and evaluation. Review of International Studies 14(1): 29-44.

Guzzini S (2000) A reconstruction of constructivism in international relations. European Journal of International Relations 6(2): 147-182.

Hall I (2002) History, Christianity and diplomacy: Sir Herbert Butterfield and international relations. Review of International Studies 28(4): 719-736.

Hall I (2006) The International Thought of Martin Wight. New York: Palgrave. Hall I (2012) Dilemmas of Decline: British Intellectuals and World Politics, 1945 1975. Berkeley and Los Angeles, CA: University of California Press.

Hall I (2019) The English School's Histories and International Relations. In Schmidt B and Guilhot N (eds) Historiographical Investigations in International Relations, New York: Palgrave.

Hay C (2011) Interpreting interpretivism interpreting interpretations: The new hermeneutics of public administration. Public Administration 89(1): 167-182. Herf J (1986) Reactionary modernism: Technology, culture, and politics in Weimar and the Third Reich. Cambridge: Cambridge University Press.

Hollis M (2002) The Philosophy of Social Science: An Introduction, revised and updated ed. Cambridge: Cambridge University Press.

Holsti K (2009) Theorising the causes of order: Hedley Bull's The Anarchical Society. In Navari C (ed) Theorising International Society: English School Methods. Basingstoke: Palgrave, pp.125-147.

Jackson, PT (2020) The Dangers of Interpretation: C.A.W. Manning and the 'going concern' of international society, Journal of International Political Theory. 
Jackson RH (1995) The political theory of international society. In Booth K and Smith S (eds) International Relations Theory Today. Cambridge: Polity Press. Jackson RH (1996) Is there a classical international theory?, in Booth K, Smith S, and Zalewski M (eds.) International Theory: Positivism and Beyond. Cambridge: Cambridge University Press, pp.203-218.

Jackson RH (2000) The Global Covenant: Human Conduct in a World of States. Oxford: Oxford University Press.

Jackson, RH (2009) International relations as a craft discipline. In Navari C (ed.) Theorising International Society: English School Methods. Basingstoke: Palgrave, pp.21-38.

James A (1982) Michael Nicholson on Martin Wight: a mind passing in the night. Review of International Studies 8(2): 117-123.

James, A (1986) Sovereign Statehood: The Basis of International Society. London: Allen and Unwin.

Jeffery R (2008) Australian realism and international relations: John Anderson and Hedley Bull on ethics, religion and society. International Politics 45(1): 5271.

Jones RE (1981) The English school of international relations: a case for closure. Review of International Studies 7(1): 1-13.

Kaplan M (1957) System and Process in International Politics. London: John Wiley and Sons.

Keene E (2008) The English School and British Historians. Millennium: Journal of International Studies 37(2): 381-393. 
Little R (1995) Neorealism and the English School: a methodological, ontological and theoretical reassessment. European Journal of International Relations 1(1): 934.

Little R (2000) The English School's contribution to the study of international relations. European Journal of International Relations 6(3): 395-422.

Linklater, A (1998) The Transformation of Political Community: Ethical Foundations of the Post-Westphalian Era, Cambridge: Polity.

Linklater A and Suganami H (2006) The English School of International Relations: A Contemporary Reassessment. Cambridge: Cambridge University Press.

Long D (2005) C. A. W. Manning and the discipline of international relations. The Round Table: The Commonwealth Journal of International Affairs 94(378): $77-96$.

Mayall, J (1990) Nationalism and International Society. Cambridge: Cambridge University Press.

Mirowski, P (2011) Realism and neoliberalism: From reactionary modernism to postwar conservatism. In Guilhot N (ed.) The Invention of International Relations Theory: Realism, the Rockefeller Foundation, and the 1954 Conference on Theory. New York: Columbia University Press, pp.210-238. Murray, R W (2013) The Need for an English School Research Program. In Murray R W (ed.) System, Society \& the World: Exploring the English School of International Relations. Bristol: e-IR, pp.67-71.

Navari C (2009) Introduction: methods and methodology in the English School. Navari C (ed.) Theorising International Society: English School Methods. Basingstoke: Palgrave, pp.1-20. 
Neufeld M (1993) Interpretation and the "science" of international relations. Review of International Studies 19(1): 39-61.

Nicholson M (1981) The Enigma of Martin Wight. Review of International Studies $7(1): 15-22$.

Oakeshott M (1933) Experience and its Modes. Cambridge: Cambridge University Press.

Oppermann K and Spencer A. (2016) Telling stories of failure: narrative constructions of foreign policy fiascos. Journal of European Public Policy 23(5): 685-701.

den Otter S (1996) British Idealism and Social Explanation. Oxford: Clarendon Press. den Otter S (2007) The origins of a historical political science in late Victorian and Edwardian Britain. In Adcock R, Bevir M and Stimson S (eds), Modern Political Science: Anglo-American Exchanges since 1880. Princeton, NJ: Princeton University Press, pp.37-65.

Pouliot, V (2016) International Pecking Orders: The Politics and Practice of Multilateral Diplomacy, Cambridge: Cambridge University Press.

Purnell R (1973) The Society of States: An Introduction to International Politics. London: Weidenfeld and Nicolson.

Rengger N (1992) A city which sustains all things? Communitarianism and international society. Millennium: Journal of International Studies 21(3): 353369.

Reus-Smit C (2002). Imagining society: constructivism and the English School, The British Journal of Politics and International Relations 4(3): 487-509.

Ross D (1991) The Origins of American Social Science. Cambridge: Cambridge University Press. 
Saler M (2017) History. In: Bevir M (ed) Modernism and the Social Sciences.

Cambridge: Cambridge University Press, 202-230.

Shapcott R (1994) Conversation and coexistence: Gadamer and the interpretation of international society. Millennium: Journal of International Studies 23: 57-83.

Smith S, Booth K and Zalewski M (eds) (1996) International theory: positivism and beyond. Cambridge: Cambridge University Press.

Stapledon, J (1994) Englishness and the Study of Politics: The Social and Political Thought of Ernest Barker. Cambridge: Cambridge University Press.

Stapleton J (2005) Sir Arthur Bryant and National History in Twentieth-Century Britain. Lanham, MD: Lexington Books.

Stephenson, E (2019) Domestic challenges and international leadership: a case study of women in Australian international affairs. Australian Journal of International Affairs 73(3): 234-253.

Suganami H (1983) The structure of institutionalism: An anatomy of British mainstream international relations. International Relations 7(5): 2363-2381.

Suganami H (2001) C. A. W. Manning and the study of international relations. Review of International Studies 27(1): 91-107.

Suganami H (2003) British institutionalists, or the English School, 20 years on. International Relations 17(3): 253-271.

Vigezzi B (2005) The British Committee on the Theory of International Politics (1954-1985): The Rediscovery of History. Milano: Edizioni Unicopli.

Vincent RJ (1974) Nonintervention and International Order. Princeton, NJ: Princeton University Press.

Vincent, RJ (1986) Human Rights and International Relations. Cambridge: Cambridge University Press. 
Wallas G (1908) Human Nature in Politics. London: Archibald Constable.

Wight M (1946) Power Politics, Looking Forward Pamphlet, no. 8. London: Royal Institute of International Affairs.

Wight M (1950) History and judgment: Butterfield, Niebuhr and the technical historian. The Frontier: A Christian Commentary on the Common Life 1(8): 301-314.

Wight M (1955) What makes a good historian? The Listener 53(1355): 283-284.

Wight M (1966a) Why is there no international theory? In Butterfield $\mathrm{H}$ and Wight $\mathrm{M}$ (eds), Diplomatic Investigations: Essays on the Theory of International Politics. London: George Allen \& Unwin, pp.17-34.

Wight M (1966b) Western values in international relations. In Butterfield H and Wight M (eds), Diplomatic Investigations: Essays on the Theory of International Politics. London: George Allen \& Unwin, pp.89-131.

Wight M (1977) Systems of States, ed. Hedley Bull. Leicester: Leicester University Press.

Wight M (1990) International Theory: The Three Traditions, ed. G Wight and B Porter. London: Leicester University Press.

Wight M (2005) Four Seminal Thinkers in International Theory: Machiavelli, Grotius, Kant, and Mazzini, ed. G Wight and B Porter. Oxford: Oxford University Press.

Wilson, P (1989) The English school of international relations: A Reply to Grader. Review of International Studies 15(1): 49-58. 
${ }^{1}$ We are, of course, not the first to claim that the English school has interpretivist concerns. See, for example, Suganami 1983: 2365; Wilson 1989: 53-54; Dunne 1998: 7-9, as well as Jackson 2020.

${ }^{2}$ On interpretivism, see especially Bevir and Blakely 2019.

${ }^{3}$ This phrase may recall the concept of 'reactionary modernism' (see Herf 1986; Mirowski 2011), which blended German romanticism and enthusiasm for modern technology. Our reluctant modernism ran in parallel, combining a commitment to historicism with a begrudging respect for some modernist social science.

${ }^{4}$ Developmental historicism also survived in a weakened form, especially in English popular histories. See Stapledon 1994; Stapledon 2005.

${ }^{5}$ On Manning, see Long 2005 and Suganami 2001. On Manning and Wight, see Bull 1977.

${ }^{6}$ This compromise was limited - Wight at the same time compared the social sciences to astrology (Wight 1957; Chiaruzzi 2016) - and involved the recognition that the comparative method originated with Aristotle, not modernists (Wight 1950). On his borrowing of a concept of institution from anthropology and sociology, see Wight 1990: 140-141, where he cites Morris Ginsberg and H. P Fairchild's Dictionary of Sociology.

${ }^{7}$ Wight's later studies of state-systems also used the comparative method (Wight 1977).

${ }^{8}$ Butterfield created the British Committee on the Theory of International Politics (BCTIP) in which much of the English school's early work was done. It was initially funded by the Rockefeller Foundation, and met, not always regularly, from 1959 to 1984. See especially Dunne 1998 and Vigezzi 2005. 
${ }^{9}$ Butterfield and Wight did not cite proponents of this 'antithesis', but most likely they had Morton Kaplan (1957) and John Burton (1965) in mind. Butterfield and Wight indicated that the BCTIP intended to produce a second volume exploring these theoretical differences, but it was never published.

${ }^{10}$ For this reason, Navari rightly argues that Bull's critique of modernism was epistemological, above all $(2009,2)$.

11 There were, of course, responses to other points made. See James 1982 and Grader.

${ }^{12}$ For a useful contemporary collection, see Fawn and Larkins 1996.

${ }^{13}$ On the similarities with structural functionalism, see Navari 2009, 1-20. 